\title{
Effect of Clay Particle Size on Clay-Escherichia coli-Bacteriophage Interactions
}

\author{
By MARGARET M. ROPER AND K. C. MARSHALL \\ School of Microbiology, The University of New South Wales, \\ Kensington, New South Wales 2033, Australia
}

(Received 15 December 1977)

Certain clays as well as particulates derived from sediments were found by Roper \& Marshall (1974) to inhibit the host-parasite interaction between Escherichia coli and a specific bacteriophage. This effect may involve more than one type of sorption phenomenon, since there are functional differences between the sorption of bacteria to particles of bacterial size and larger (Meadows, 1965; Santoro \& Stotzky, 1967) and the sorption of colloidal particles to a bacterial surface (Peele, 1936; Lahav, 1962; Marshall, 1968, 1969 a, b). Roper \& Marshall (1974) suggested that, at low electrolyte concentrations, E. coli is protected from bacteriophage attack by an envelope of colloidal particles sorbed to the bacterium, whereas, at high electrolyte concentrations, protection may result both from the presence of a colloidal envelope and from sorption of $E$. coli and bacteriophage to larger particulate material.

The purpose of this investigation was to define more accurately the effects of different particle-size fractions of a montmorillonite on the $E$. coli-bacteriophage interaction at both high and low electrolyte concentrations.

An aqueous suspension of montmorillonite, prepared from Wyoming bentonite (Volclay, American Colloid Co., Skokie, Illinois, U.S.A.), was centrifuged at $12000 \mathrm{~g}$ for $20 \mathrm{~min}$ and the supernatant was retained. The pellet was resuspended in distilled water, centrifuged at the same speed and the supernatant was combined with the original supernatant. This procedure was repeated until no montmorillonite remained in the supernatant. Similar centrifugations were carried out at separate, decreasing $g$ values to give eight particle-size fractions. The effective spherical diameter was then calculated using Stokes' equation (Day, 1965):

$$
v=X^{2} \boldsymbol{g}\left(\rho_{\mathrm{s}}-\rho_{\mathrm{L}}\right) / 18 \eta
$$

in which $X$ is the effective spherical diameter, $\rho_{\mathrm{s}}$ is the density of solid particles $\left(2.60 \mathrm{~g} \mathrm{~cm}^{-3}\right)$, $\rho_{\mathrm{L}}$ is the liquid density $\left(1 \mathrm{~g} \mathrm{~cm}^{-3}\right), \eta_{2^{0}}$ is the viscosity of water at $20^{\circ} \mathrm{C}(0.010042$ poise $)$, and $v=h / t$, in which $h$ is the distance of sedimentation $(8 \mathrm{~cm})$, and $t$ is the time of sedimentation (20 min).

Survival of $E$. coli in the presence of the various montmorillonite fractions was determined in $\mathrm{NaCl}$ solutions both at a relatively high specific conductance $\left(L_{\mathrm{s}}=13.9 \mathrm{mS} \mathrm{cm}{ }^{-1}\right)$ and at a low specific conductance $\left(L_{\mathrm{s}}=1.39 \mathrm{mS} \mathrm{cm}^{-1}\right)$. The montmorillonite was dispersed at specific conductance values below $2 \cdot 2 \mathrm{mS} \mathrm{cm}^{-1}$ (Roper \& Marshall, 1974). The treatments employed in the experiments were: (i) E. coli $\left(8 \times 10^{8} \mathrm{ml}^{-1}\right)$ plus $1.0 \mathrm{ml}$ spent nutrient broth; (ii) E. coli plus $1.0 \mathrm{ml}$ bacteriophage in spent nutrient broth; (iii) $E$. coli plus spent nutrient broth plus montmorillonite fraction $\left(150 \mu \mathrm{g} \mathrm{ml}^{-1}\right.$, final concentration); and (iv) E. coli plus bacteriophage in spent nutrient broth plus montmorillonite fraction. Spent nutrient broth was used in treatments (i) and (iii) to ensure that nutrient additions were the same as in treatments with phage, which were suspended in filtered spent nutrient broth. All treatments were incubated in $250 \mathrm{ml}$ Erlenmeyer flasks on a gyratory shaker for $16 \mathrm{~h}$ at $28^{\circ} \mathrm{C}$, after which $E$. coli numbers were determined. In all instances, samples containing montmorillonite were diluted to $L_{s}=0.695 \mathrm{mS} \mathrm{cm} \mathrm{cm}^{-1}$ to desorb the bacteria prior to plating on Mac- 


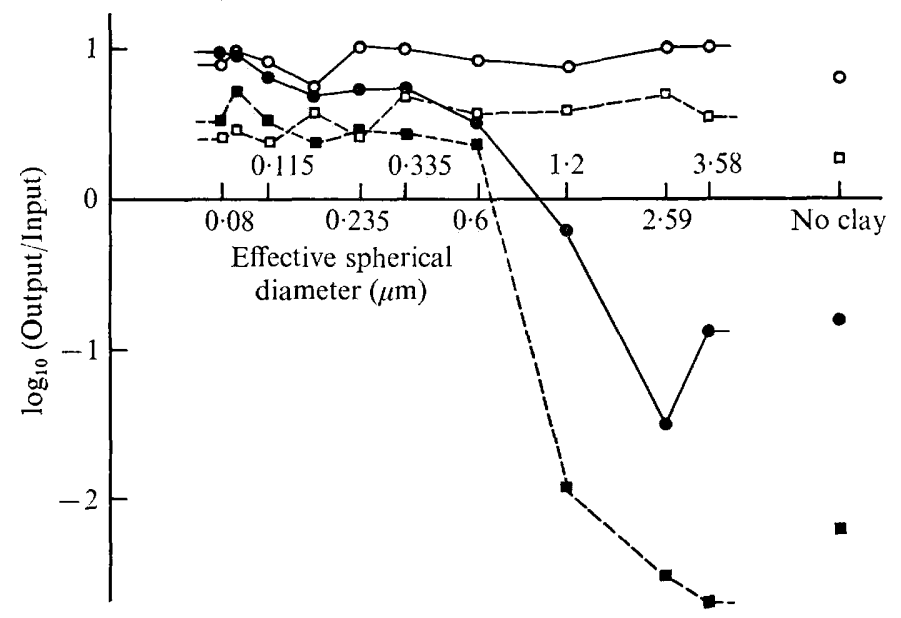

Fig. 1. Effect of particle-size of montmorillonite on the survival of $E$. coli in the presence or absence of bacteriophage. Output/Input $=$ total number of $E$. coli recovered/initial inoculum. Positive values of $\log _{10}$ (Output/Input) represent growth and negative values represent death. At $L_{\mathrm{s}}=13.9 \mathrm{mS} \mathrm{cm}^{-1}: \bigcirc$, no phage; 0 , with phage. At $L_{s}=1.39 \mathrm{mS} \mathrm{cm}^{-1}: \square$, no phage; $\mathbf{n}$, with phage.

Conkey agar (Roper \& Marshall, 1974); numbers of E. coli were adjusted for the volume of diluent employed.

The results (Fig. 1) indicate that] almost complete protection of E. coli from phage attack was provided by the fine particles. However, particles with an effective spherical diameter greater than $0.6 \mu \mathrm{m}$ did not protect $E$. coli from phage lysis. The electrolyte concentration had little or no effect on the survival of $E$. coli with particles of different sizes. Colloidal particles attach to bacterial surfaces as a result of electrostatic attraction (Marshall, 1971), but colloidal particles exceeding $0.6 \mu \mathrm{m}$ effective spherical diameter may not form a continuous barrier around the bacterium. Thus, phage may make contact with the host surface and cause lysis. This view may be too simplistic because Bystricky, Stotzky \& Schiffenbauer (1975) found that although bacteriophage sorbed to clay particles by their tails this did not reduce their ability to infect available hosts (Stotzky, 1977). However, these authors were working with clays in the larger effective spherical diameter range (G. Stotzky, personal communication).

The results presented here indicate that the inhibition of E. coli-bacteriophage interaction by colloidal particulates is dependent upon particle size, thereby emphasizing the subtlety of interactions between micro-organisms and certain physical components of their habitat. In addition, the protection of $E$. coli and other faecal bacteria in aquatic systems by particulate matter may have important consequences from a public health viewpoint.

This investigation was supported by a grant from the Australian Water Resources Council.

\section{REFERENCES}

Bystricky, V., Stotzky, G. \& Schiffenbauer, M. (1975). Electron microscopy of $T_{1}$-bacteriophages adsorbed to clay minerals: application of the critical point drying method. Canadian Journal of Microbiology 21, 1278-1282.

DAY, P. R. (1965). Particle fractionation and particle-size analysis. In Methods of Soil Analysis, part 1, pp. 545-567. Edited by C. A. Black, D. D. Evans, L. E. Ensminger, J. L. White and

F. E. Clark. Madison: American Society of Agronomy.

LAHAV, N. (1962). Adsorption of sodium bentonite particles on Bacillus subtilis. Plant and Soil 17, 191-208.

MARSHALL, K. C. (1968). Interaction between colloidal montmorillonite and cells of Rhizobium species with different ionogenic surfaces. Biochimica et biophysica acta 156, 179-186. 
Marshall, K. C. (1969a). Studies by microelectrophoretic and microscopic techniques of the sorption of illite and montmorillonite to rhizobia. Journal of General Microbiology 56, 301-306.

Marshall, K. C. $(1969 b)$. Orientation of clay particles sorbed on bacteria possessing different ionogenic surfaces. Biochemica et biophysica acta 193, 472-474.

Marshall, K. C. (1971). Sorptive interactions between soil particles and microorganisms. In Soil Biochemistry, vol. 2, pp. 409-445. Edited by A. D. McLaren and J. Skujins. New York: Marcel Dekker.

Meadows, P. S. (1965). Attachment of marine and freshwater bacteria to surfaces. Nature, London 207, 1108.

PeEle, T. C. (1936). Adsorption of Bacteria by Soils, Cornell University Agricultural Experiment Station, Memoir No. 197, pp. 3-18.
Roper, M. M. \& MARshall, K. C. (1974). Modification of the interaction between Escherichia coli and bacteriophage in saline sediment. Microbial Ecology 1, 1-13.

SAntoro, T. \& Stotzky, G. (1967). Effect of electrolyte composition and $\mathrm{pH}$ on the particle size distribution of microorganisms and clay minerals as determined by the electrical sensing zone method. Archives of Biochemistry and Biophysics 122, 664-669.

Stotzky, G. (1977). Interactions of organics, viruses, and microorganisms with clay minerals and their importance in microbial environments. In Abstracts of the Third International Symposium on Environmental Biogeochemistry, Wolfenbüttel, Germany, p. 116. 